\title{
Pig slurry composting as a nitrogen source in proso millet crop ${ }^{1}$
}

\author{
Alieze Nascimento da Silva², Claudir José Basso², \\ Dionei Schmidt Muraro ${ }^{2}$, Cícero Ortigara ${ }^{2}$, Edivan Pansera ${ }^{2}$
}

\section{ABSTRACT}

With the intensification of pig farming systems, in Brazil, the production of swine waste has increased considerably, leading to water and soil contamination, due to its improper release. Pig slurry composting is an alternative that can be used in order to avoid or reduce negative impacts, especially for producers with physically limited farm areas, or those who intend to increase the number of animals in their production units. This study aimed at evaluating the influence of pig slurry compost doses on the agronomic characteristics and grain yield of proso millet. A randomized blocks design experiment was installed with four replications and five treatments: control without fertilization, control with mineral fertilizer (NPK) and pig slurry compost doses $\left(4.0 \mathrm{Mg} \mathrm{ha}^{-1}\right.$, 8.0 $\left.\mathrm{Mg} \mathrm{ha}^{-1} ; 12.0 \mathrm{Mg} \mathrm{ha}^{-1}\right)$. The pig slurry composting increased the dry matter yield, number of grains per plant and grain yield of proso millet, when compared to the control with or without mineral fertilizer. The proso millet yield, at the doses of $8.0 \mathrm{Mg} \mathrm{ha}^{-1}$ and $12.0 \mathrm{Mg} \mathrm{ha}^{-1}$ of pig slurry, was superior than for both the control without fertilization and the control with the recommended mineral fertilizer, with the latter reaching a maximum agronomic efficiency at the dose of $8.0 \mathrm{Mg} \mathrm{ha}^{-1}$.

KEY-WORDS: Panicum miliaceum L.; organic waste; mineral nutrition; grain yield.

\section{INTRODUCTION}

The swine farming system has been intensified in some regions of Brazil, leading to a significant increase in the volume of manure (Conti et al. 2016), which is usually stored in liquid form (Makara \& Kowalski 2015) and released on crops and pastures (Meade et al. 2011).

The disposal of waste in fields is a serious issue, when considering the sustainability of the swine

\section{RESUMO}

Compostagem de dejetos líquidos de suínos como fonte de nitrogênio na cultura de painço

Com a intensificação dos sistemas de criação de suínos, no Brasil, a produção de dejetos cresceu consideravelmente, provocando problemas de contaminação da água e solo, devido à sua aplicação inadequada. A compostagem de dejetos líquidos de suínos surge como alternativa para evitar ou reduzir impactos negativos, principalmente para produtores com limitação de áreas físicas, ou que visem ao aumento do número de animais na unidade de produção. Objetivouse avaliar o efeito de doses de compostagem de dejetos líquidos de suínos nas características agronômicas e produtividade de grãos de painço. O delineamento experimental foi em blocos ao acaso, com quatro repetições e cinco tratamentos, os quais consistiram em testemunha sem adubação, testemunha com adubação mineral (NPK) e doses de compostagem de dejetos líquidos de suínos $\left(4,0 \mathrm{Mg} \mathrm{ha}^{-1}\right.$; $\left.8,0 \mathrm{Mg} \mathrm{ha}^{-1} ; 12,0 \mathrm{Mg} \mathrm{ha}^{-1}\right)$. A compostagem de dejetos líquidos de suínos promoveu incremento na produção de massa seca, número de grãos por planta e produtividade de grãos de painço, em relação às testemunhas sem adubação e com aubação mineral. A resposta do painço para produtividade, nas doses de $8,0 \mathrm{Mg} \mathrm{ha}^{-1}$ e $12,0 \mathrm{Mg} \mathrm{ha}^{-1}$, mostrou-se superior à das testemunhas sem adubação e com adubação mineral recomendada para a cultura, sendo que esta apresenta máxima eficiência agronômica para a dose de $8,0 \mathrm{Mg} \mathrm{ha}^{-1}$.

PALAVRAS-CHAVES: Panicum miliaceum L.; resíduos orgânicos; nutrição mineral; produtividade de grãos.

production chain, mainly due to the increasing demand of swines in the international market (Steinfeld et al. 2006). Unlike European countries, Brazil does not have specific rules for the treatment and disposal of liquid waste produced. In Germany, the surface application of manure has been prohibited and, in the Netherlands, is not allowed to open new pig farms (Van Ruiten 1998). Thus, there is a need for strategies to reduce the volume of swine waste, maximize their fertilization potential and reduce the environmental pollution. 
An alternative technology is the pig slurry composting (PSC), in which liquid manure is mixed with sawdust substrate with a high $\mathrm{C} / \mathrm{N}$ ratio. The mixture is constantly revolved for the evaporation of water excess in the urine and feces of animals (Fukumoto et al. 2011). The liquid manure/substrate ratio is typically greater than $8: 1$, to increase the concentration of pig slurry nutrients and significantly reduce the volume of waste generated. Sawdust has a high absorbing capacity, aiding the aerobic decomposition of the material (Huang et al. 2006, Barrena et al. 2011). PSC is easy to transport and use and has a high nutrient concentration and agronomic value (Bustamante et al. 2013). Due to the reduction in the volume of waste produced, PSC enables farmers to increase the number of animals per unit area (Lindner 1995). The dry matter content in PSC is higher (53\%) than in pig slurry, and $\mathrm{N}$ is mostly in organic form.

The mineralization of organic $\mathrm{N}$ occurs slowly and gradually, and may increase the synchronism of $\mathrm{N}$ demand by crops and $\mathrm{N}$ availability (Berrena et al. 2011). Also, $\mathrm{N}$ in pig slurry is already in mineral form and available to plants (Prapaspongsa et al. 2010). Nitrogen (along with phosphorus) is also susceptible to being lost to the environment, what can cause eutrophication problems (Vitousek et al. 2009, MacDonald et al. 2011) and enhance the emission of $\mathrm{NH}_{3}, \mathrm{CO}_{2}$ and $\mathrm{N}_{2} \mathrm{O}$ to the atmosphere (Thu et al. 2012). Therefore, PSC efficiency as a source of $\mathrm{N}$ for plants is higher than that provided by the liquid waste (Berrena et al. 2011).

Evaluating the potential $\mathrm{N}$ supply from pig slurry and deep-litter manure in maize, Giacomini \& Aita (2008) concluded that although the application of deep-litter pig manure increased maize grain yield, when compared to non-fertilization treatments, pig slurry has immediate effects similar to the application of urea as a nitrogen source. This is explained by the fact that pig slurry has a low dry matter and high ammoniacal nitrogen content (40-70\% total $\mathrm{N}$ ), while the manure in solid form has a high dry matter and high $\mathrm{N}$ content in organic form (70-90\% total N) (Giacomini et al. 2013).

In maize, the application of composts from catle and poultry manure resulted in higher grain yield, when compared to mineral fertilization (Lyimo et al. 2012), and PSC (180 $\mathrm{m}^{3} \mathrm{ha}^{-1}$ year $\left.^{-1}\right)$ application in Brachiaria bizantha cv. Marandu resulted in dry matter yield similar to that obtained with mineral fertilizer (Medeiros et al. 2007).
Crops generally use $\mathrm{N}$ from pig slurry more efficiently than from mineral fertilizers. Sieling et al. (2014) compared the effects of pig slurry application and mineral fertilization on canola, wheat and barley, for 13 years in a test field, and found that their yield was slightly higher with the pig slurry application. Due to the high $\mathrm{N}$ content in swine waste and the high demand of $\mathrm{N}$ by grass crops, in most cases, these plants have linear and positive responses to the swine waste application. There are, however, few studies that evaluate the responte of proso millet crops (Panicum miliaceum L.) to swine manure compost.

Proso millet is a short cycle grass ( $\mathrm{Lu}$ et al. 2009), which responds to the positive supply of $\mathrm{N}$ (Basso et al. 2015). The grass has emerged as an alternative to crop rotation under no-tillage, and is cultivated mainly in the spring. It has attracted the attention of producers because its short cycle is ideal for rotation with soybean, which can be seeded in its seasonally preferred time (Basso et al. 2015). Proso millet cultivation enables a significant increase of straw in the system, and has a low cost to the producer. Proso millet grains can be used to feed birds (Abrantes et al. 2010) and produce beer (Zarnkow et al. 2010) and ethanol (Rose \& Santra 2013).

Given the fertilizer potential of PSC and the fact that proso millet requires large amounts of nitrogen, the assumption of this research is that the proso millet crop responds positively to PSC fertilization, replacing all or part of the mineral fertilization in the following cash crop. Therefore, this study aimed at evaluating the effect of PSC doses on agronomic characteristics and grain yield of proso millet.

\section{MATERIAL AND METHODS}

The study was conducted in the experimental area of the Universidade Federal de Santa Maria, in Frederico Westphalen $\left(27^{\circ} 23^{\prime} \mathrm{S}, 53^{\circ} 25^{\prime} \mathrm{W}\right.$ and altitude of 566 m), Rio Grande do Sul State, Brazil, in 2013 and 2014. The local climate is humid subtropical (CFA), according to the Köppen classification (Moreno 1961). Meteorological data for the maximum and minimum air temperatures and daily precipitation were collected from an automatic weather station located $500 \mathrm{~m}$ from the experiment site, being electronically recorded in one minute intervals, with values integrated for daily data (Figure 1). 
The soil is classified as Rhodic Hapludox (Embrapa 2013). In order to avoid residual and cumulative effects on the soil, the manure was applied in two different areas (500 m apart) for different years (2013 and 2014). During the implementation of the experiment, soil samples were collected from the $0-20 \mathrm{~cm}$ depth layer, at the beginning of the experiment, in both years (Table 1). Six months before the experiment, lime was applied to the soil in order to raise the $\mathrm{pH}$ to 6.0 (CQFS-RS/ SC 2004).

A randomized blocks design, with four replications and five treatments, where each plot had an area of $4.0 \mathrm{~m} \times 3.6 \mathrm{~m}\left(14.4 \mathrm{~m}^{2}\right)$, was used. The treatments consisted of a control with mineral fertilizer (NPK) and without fertilization and PSC doses (4.0 Mg ha' $\mathrm{Mg}^{-1}$, $.0 \mathrm{Mg} \mathrm{ha}^{-1}$ and $12.0 \mathrm{Mg} \mathrm{ha}^{-1}$ ).

The experiment was conducted under a notillage system. In both years, a culture succession of proso millet/soybean (Glycine max) was implemented. After the soybean harvest, the area remained in a fallow period of three months.

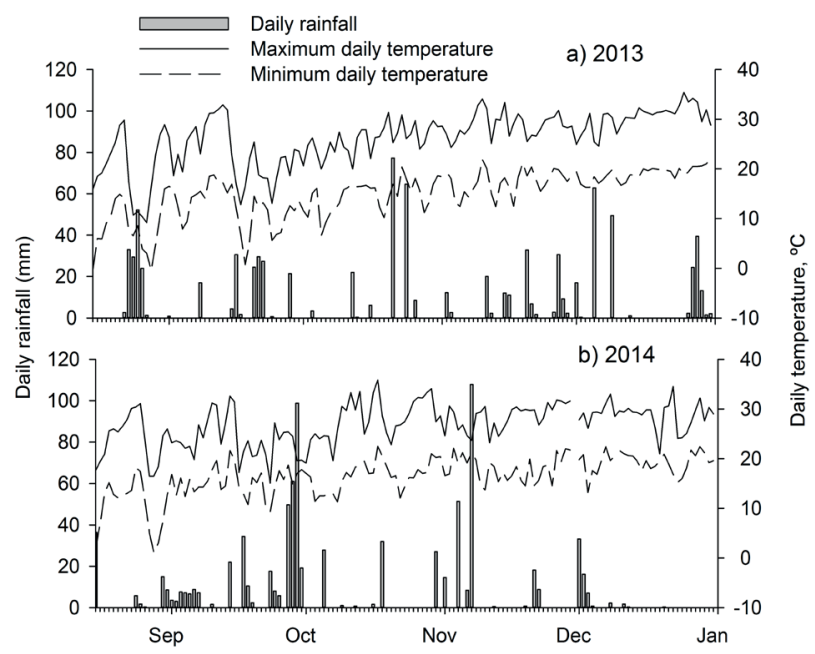

Figure 1. Average daily temperature and rainfall during the experiment (2013 and 2014). The rainfall data were obtained from a meteorological station in Frederico Westphalen, Rio grande do Sul State, Brazil.
The area was subjected to one application of glyphosate $\left(3.0 \mathrm{~L} \mathrm{ha}^{-1}\right)$ for experimental setup. The proso millet seeding process was held manually on September 14 (2013) and August 22 (2014), using the AL Tibagi cultivar, spaced $0.45 \mathrm{~m}$ between rows and with a density of 120 seeds $\mathrm{m}^{-1}$. The emergence of proso millet occurred about 10 days after seeding, for both years. The cycles of the experiments were 98 and 83 days, respectively for 2013 and 2014.

A compost sample was collected and sent to a laboratory for analyses (Tedesco et al. 1995). The same PSC was used in both years and the chemical composition and amount of nutrients added to each administered dose is shown in Table 1.

The PSC doses were manually applied to the crop in each year, immediately after the proso millet seeding. For the mineral fertilizer, a manual process was also used (CQFS-RS/SC 2004). The $\mathrm{N}$ was applied as urea (100 kg ha-1 of N), $\mathrm{P}_{2} \mathrm{O}_{5}$ in the form of single superphosphate $\left(60 \mathrm{~kg} \mathrm{ha}^{-1}\right.$ of $\left.\mathrm{P}_{2} \mathrm{O}_{5}\right)$ and $\mathrm{K}_{2} \mathrm{O}$ in the form of potassium chloride $\left(40 \mathrm{~kg} \mathrm{ha}^{-1}\right)$.

The following characteristics were evaluated in the proso millet crop: a) dry matter: an area of $0.25 \mathrm{~m}^{2}$ was sampled during full bloom and dried at $65{ }^{\circ} \mathrm{C}$, until constant weight; b) plant height: measured from the soil surface to the top of the panicle of the main stem. Ten plants were randomly chosen for this measurement within the cultivated area of each plot and later the average was assessed; c) panicle length: obtained by averaging the distance from the insertion of the first branch of the rachis to the upper end of the panicle, in 10 plants randomly chosen within the cultivated area of each plot; d) number of grains per panicle: obtained by counting the number of grains in three panicles, which were randomly harvested in the cultivated area of each plot; e) 1,000 grains weight: weight of five samples of 1,000 seeds randomly collected in each plot, with values corrected to $13 \%$ moisture; f) grain yield: evaluated by manual harvesting in the 4 centered lines, discarding $0.3 \mathrm{~m}$ from each plot, in a total area of $2.7 \mathrm{~m}^{2}$. Soil tilling and furrowing

Table 1. Soil test results at the $0-20 \mathrm{~cm}$ depth layer, before the installation of the experiments.

\begin{tabular}{|c|c|c|c|c|c|c|c|c|c|c|c|c|c|}
\hline \multirow{2}{*}{ Year } & $\mathrm{P}^{1}$ & $\mathrm{~K}$ & $\mathrm{Ca}$ & $\mathrm{Mg}$ & $\mathrm{H}+\mathrm{A}$ & $\mathrm{Al}$ & $\mathrm{CEC}^{2}$ & $\mathrm{OM}^{3}$ & Clay & \multirow{2}{*}{$\begin{array}{l}\mathrm{SMP}^{4} \\
\text { index }\end{array}$} & \multirow{2}{*}{$\begin{array}{c}\mathrm{pH} \\
\left(\mathrm{H}_{2} \mathrm{O}\right)\end{array}$} & $\mathrm{V}^{5}$ & $\mathrm{~m}^{6}$ \\
\hline & \multicolumn{2}{|c|}{$-\mathrm{mg} \mathrm{dm}^{-3}-$} & & & $\mathrm{cmol}_{\mathrm{c}} \mathrm{d}$ & & & \multicolumn{2}{|c|}{$-\mathrm{g} \mathrm{kg}^{-1}-$} & & & \multicolumn{2}{|c|}{$\%$} \\
\hline 2013 & 7.2 & 137 & 2.1 & 1.2 & 8.0 & 2.1 & 11.6 & 2.7 & 650 & 5.1 & 4.6 & 31.3 & 36.5 \\
\hline 2014 & 6.9 & 219 & 3.1 & 2.4 & 6.1 & 0.5 & 12.2 & 3.0 & 700 & 5.4 & 5.0 & 49.8 & 7.6 \\
\hline
\end{tabular}


were performed with furrowing equipment and grain weight was corrected to $13 \%$ moisture; g) stem diameter: determined in the first internode above the plant stem, with a digital caliper.

Statistical analysis was conducted with the softwares Genes (Cruz 2006) and Sigma Plot, version 12.5 (Systat Software, Inc.), for graphing the main results. The means of the variables related to PSC doses were compared to the control plants and treatments with mineral fertilizers by the Dunnet test at $5 \%$. The effects of PSC doses were assessed by regression analysis.

\section{RESULTS AND DISCUSSION}

In the crop cycle, $602 \mathrm{~mm}$ of precipitation were recorded during the 2013 experiment and $680 \mathrm{~mm}$ in 2014 (Figure 1). This amount of rainfall is within the average for the region (Brasil 2016). During the first growing season, the precipitation was well distributed, with frequent rains occuring at intervals of 15 days. During the second cultivation period, the proso millet crop suffered two drought intervals, with a 12-days period in full bloom, that occurred 42 days after emergence (Figure 1b). Thus, water availability during the second year of cultivation may have been a limiting factor to the crop development and yield (Moreno et al. 2014). The second year of cultivation had overall lower millet yield than the first year (Table 3). In addition, the productive response and agronomic characteristics of grasses are highly dependent on air temperature, especially for species of the Panicum spp. genus (Moreno et al. 2014). Proso millet is a kind of crop that grows best in cold climates. When compared to 2013, in 2014, during the initial phase of the crop development, the minimum temperatures were considered high and may have compromised the early development of proso millet.
PSC doses significantly influenced most the variables studied, when compared to the control plants (mineral fertilizer) (Table 3). Nutrients supply, in organic or inorganic form, positively influenced the proso millet grain yield, when compared to the control without fertilizer (Figure 2, Table 2). In 2013, PSC doses induced a quadratic response in the proso millet grain yield (Figure $2 \mathrm{a}$ ). The maximum agronomic efficiency was $4,360 \mathrm{~kg} \mathrm{ha}^{-1}$, using a dose of $8.0 \mathrm{Mg} \mathrm{ha}^{-1}$. Similar results were observed by Soratto et al. (2007), who used mineral fertilization with $\mathrm{N}$ in proso millet. They also observed a quadratic response in grain yield, which was maximum under a dose of $120 \mathrm{~kg} \mathrm{ha}^{-1}$ of $\mathrm{N}$. For the doses of 8.0 $\mathrm{Mg} \mathrm{ha}^{-1}$ and $12.0 \mathrm{Mg} \mathrm{ha}^{-1}$ of PSC, $278.4 \mathrm{~kg} \mathrm{ha}^{-1}$ and $417.8 \mathrm{~kg} \mathrm{ha}^{-1}$ of $\mathrm{N}$ were respectively applied, considering that around $48 \%$ of the N present in PSC was mineralizable (Table 2). This compost contains higher $\mathrm{N}$ content, when compared to the maximum dose of $120 \mathrm{~kg} \mathrm{ha}^{-1}$ used by Soratto et al. (2007).

For the 2014 experiment, proso millet grain yield responded linearly to PSC doses (Figure 2b), with the highest value observed for the dose of 12.0 $\mathrm{Mg} \mathrm{ha}^{-1}\left(2,309 \mathrm{~kg} \mathrm{ha}^{-1}\right)$. These differences in responses of grain yield for both years may be related to climate conditions, as previously discussed. The linear response for years with water deficit may be associated to the increased organic material in higher doses $\left(4 \mathrm{Mg} \mathrm{ha}^{-1}<8 \mathrm{Mg} \mathrm{ha}^{-1}<12 \mathrm{Mg} \mathrm{ha}^{-1}\right.$ ) on the soil surface, promoting the formation of a physical barrier to ground water loss by evaporation (Doran \& Parkin 1994). It may also be related to low leaching, due to low volumes of rainfall, which may have preserved nutrients and reduced losses by leaching (Meade et al. 2011). In addition, the crop response to nitrogen fertilization depends on ground water availability and rainfall frequency and amount, during the growing season. Water availability may have a greater influence on cultivar development, if

Table 2. Chemical characteristics in each pig slurry compost dose.

\begin{tabular}{|c|c|c|c|c|c|c|c|c|c|}
\hline \multirow{2}{*}{ Dose } & $\mathrm{C}$ & $\mathrm{N}$ & $\mathrm{P}$ & $\mathrm{K}$ & $\mathrm{Ca}$ & $\mathrm{Mg}$ & Inorganic $\mathrm{N}^{1}$ & \multirow{2}{*}{$\mathrm{pH}$} & \multirow{2}{*}{$\mathrm{C}: \mathrm{N}$} \\
\hline & & & & $-\mathrm{g} \mathrm{kg}$ & & & & & \\
\hline \multirow{2}{*}{$\mathrm{Mg} \mathrm{ha}^{-1}$} & 199.0 & 34.8 & 14.7 & 34.6 & 36.8 & 13.5 & 15.7 & 6.8 & 5.72 \\
\hline & \multicolumn{7}{|c|}{$\mathrm{kg} \mathrm{ha}^{-1}$ added } & & \\
\hline 4.0 & 796.0 & 139.2 & 58.8 & 138.4 & 147.2 & 5.4 & 62.8 & - & - \\
\hline 8.0 & $1,592.0$ & 278.4 & 117.6 & 276.8 & 294.4 & 10.8 & 125.6 & - & - \\
\hline 12.0 & $2,388.0$ & 417.6 & 176.4 & 415.2 & 441.6 & 16.2 & 188.4 & - & - \\
\hline
\end{tabular}


Table 3. Dry matter, plant height, panicle length, number of grains per plant, grain yield, 1,000 grains weight and stem diameter of proso millet with the use of pig slurry compost and mineral fertilizer (NPK) under no-tillage system, in 2013 and 2014.

\begin{tabular}{|c|c|c|c|c|c|c|c|}
\hline $\begin{array}{l}\text { Treatment } \\
\left(\mathrm{Mg} \mathrm{ha}^{-1}\right)\end{array}$ & $\begin{array}{c}\text { Dry matter } \\
\left(\mathrm{kg} \mathrm{ha}^{-1}\right)\end{array}$ & $\begin{array}{c}\text { plant height } \\
\text { (m) }\end{array}$ & $\begin{array}{l}\text { panicle length } \\
(\mathrm{m})\end{array}$ & $\begin{array}{c}\text { Number of } \\
\text { grains plant }^{-1}\end{array}$ & $\begin{array}{c}\text { Grain yield } \\
\left(\mathrm{kg} \mathrm{ha}^{-1}\right)\end{array}$ & $\begin{array}{c}1,000 \text { grains } \\
\text { weight }\end{array}$ & $\begin{array}{c}\text { stem diameter } \\
(\mathrm{mm})\end{array}$ \\
\hline \multicolumn{8}{|c|}{2013} \\
\hline 0 & 3,907 & 1.57 & 0.360 & 767 & 2.530 & 5.32 & 4.30 \\
\hline 4 & 4,760 & 1.58 & 0.362 & 1,029 & 3.261 & 5.64 & 4.73 \\
\hline 8 & 4,879 & 1.62 & 0.357 & 1,075 & 4.360 & 5.33 & 4.81 \\
\hline 12 & 6,870 & 1.63 & 0.350 & 986 & 3.613 & 5.48 & 5.34 \\
\hline NPK & 4,788 & 1.65 & 0.371 & 1,127 & 2.719 & 5.69 & 4.20 \\
\hline \multicolumn{8}{|c|}{2014} \\
\hline 0 & 2,975 & 0.84 & 0.276 & 242 & 1.228 & 4.14 & 3.36 \\
\hline 4 & 3,363 & 0.87 & 0.273 & 392 & 1.775 & 4.41 & 3.80 \\
\hline 8 & 4,295 & 0.95 & 0.278 & 458 & 2.167 & 4.57 & 4.31 \\
\hline 12 & 4,674 & 0.94 & 0.305 & 467 & 2.309 & 4.62 & 4.45 \\
\hline NPK & 3,888 & 1.01 & 0.283 & 441 & 1.683 & 4.53 & 4.21 \\
\hline Comparison & \multicolumn{7}{|c|}{2013} \\
\hline NPK x 0 & -22.56 & ns & ns & -46.94 & ns & ns & ns \\
\hline NPK x 4 & ns & ns & ns & ns & ns & ns & ns \\
\hline NPK x 8 & ns & ns & -4.00 & ns & 37.65 & ns & ns \\
\hline NPK x 12 & 30.30 & ns & -6.03 & ns & ns & ns & 21.36 \\
\hline $0 \times 4$ & - & ns & ns & ns & - & ns & ns \\
\hline $0 \times 8$ & - & ns & ns & 28.66 & - & ns & ns \\
\hline $0 \times 12$ & - & ns & ns & ns & - & ns & 19.60 \\
\hline MSD & 646.35 & 0.08 & 0.01 & 274.08 & $1,036.52$ & 0.24 & 0.82 \\
\hline Comparison & \multicolumn{7}{|c|}{2014} \\
\hline NPK $\times 0$ & -30.69 & ns & ns & -82.75 & ns & ns & ns \\
\hline NPK $x 4$ & $\mathrm{~ns}$ & ns & ns & ns & ns & ns & ns \\
\hline NPK x 8 & ns & ns & ns & ns & ns & ns & ns \\
\hline NPK x 12 & 16.83 & ns & ns & ns & 27.10 & ns & ns \\
\hline $0 \times 4$ & - & ns & ns & ns & - & ns & ns \\
\hline $0 \times 8$ & - & ns & $\mathrm{ns}$ & 47.31 & - & ns & ns \\
\hline $0 \times 12$ & - & ns & 9.60 & 48.25 & - & $\mathrm{ns}$ & ns \\
\hline MSD & 649.21 & 0.10 & 0.0239 & 159.86 & 590.3135 & 0.71 & $1,468.49$ \\
\hline
\end{tabular}

Average results represented by $n s$ did not differ from the control with mineral fertilizer. MSD: minimum significant difference.
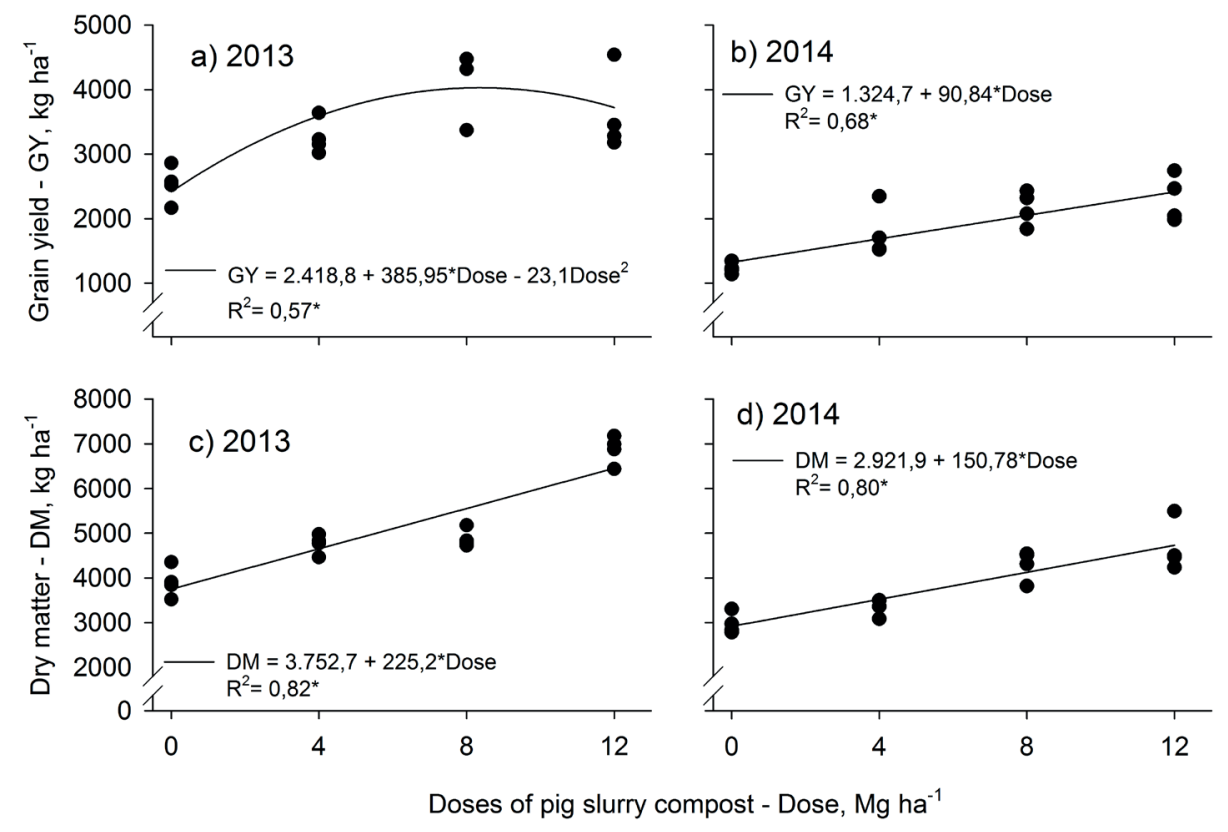

Figure 2. Grain and dry matter yield of proso millet under doses of pig slurry compost. 
compared to the amount of $\mathrm{N}$ application (Tilling et al. 2007). Water deficit conditions can lead to a reduction in the availability of nitrogen, decreasing the microbial activity and thus the organic $\mathrm{N}$ mineralization, which causes low bioavailability and uptake by plants (Wang et al. 2013). In situations of water scarcity, a reduction in $\mathrm{N}$ availability and other nutrients, such as organic phosphorus, may occur (Szogi et al. 2015).

In 2013, for the dose of $8.0 \mathrm{Mg} \mathrm{ha}^{-1}$ of PSC, the increase in proso millet grain yield was respectively $37.6 \%$ and $41.98 \%$, in comparison to the mineral fertilizer and control (Table 2). In the same year, at the dose of $12 \mathrm{Mg} \mathrm{ha}^{-1}$, the increase was $29 \%$, when compared to the control, not differing significantly from the mineral fertilizer. In 2014, for the dose of $12 \mathrm{Mg} \mathrm{ha}^{-1}$ of PSC, the increase in proso millet grain yield was respectively $27.1 \%$ and $46.8 \%$, when compared to the mineral fertilizer and control. For the dose of $8.0 \mathrm{Mg} \mathrm{ha}^{-1}$, a significant effect was observed only if compared to the control.

Several authors have observed an increase in grain yield for crops such as corn (Loecke et al. 2004, Lymo et al. 2012), soybean (Mennaled et al. 2004) and wheat (Muhammad et al. 2008), when studying the use of PSC and deep-litter pig manure. For these authors, the slow and gradual release of nutrients throughout the growing season has been the main factor contributing to the increase in grain yield. This may be associated to an increased synchronization between the release of these nutrients and the plant needs (Muneshwar et al. 2001, Nevens \& Reheul 2003), enabling a gradual long-term improvement in soil physical, chemical and biological characteristics (Hepperly et al. 2009).

For dry proso millet matter, a positive and linear response was obtained with the application of increasing PSC doses for both years (Figures 2c and 2d). In 2013 and 2014, the dose of $12 \mathrm{Mg} \mathrm{ha}^{-1}$ provided a dry matter yield of $2,082 \mathrm{~kg} \mathrm{ha}^{-1}$ and $786 \mathrm{~kg} \mathrm{ha}^{-1}$, respectively, being equivalent to an increase of $30.30 \%$ and $16.83 \%$, when compared to the mineral fertilizer (NPK).

Working with deep-litter pig manure, Locke et al. (2004) observed an increase of $12 \%$ and $15 \%$ in the dry matter yield of maize, when compared to the control plants.

PSC had no significant effect over the height of proso millet plants in both years (Table 3 ). This result differs from what was observed by other authors either with deep-litter pig manure (Mennaled et al. 2004) or with urea fertilization (Soratto et al. 2007).

The increase in panicle length was observed only in 2014 and for the dose of $12 \mathrm{Mg} \mathrm{ha}^{-1}$, which resulted in panicles $9.60 \%$ longer, when compared to the control (Table 3). PSC was applied during the crop seeding stage, what may have caused a lower $\mathrm{N}$ availability at the time of panicle differentiation. Soratto et al. (2007) studied N doses and application period on proso millet crop and found a greater panicle length with $\mathrm{N}$ application at 14 days after emergence. This is likely due to the greater $\mathrm{N}$ availability at the time of panicle differentiation. During the proso millet harvest, Jornada et al. (2005) observed that regardless of the nitrogen dose applied, there was an increase in panicle length.

Concerning the number of grains per plant, different results were obtained for the two years of study (Table 3). In 2013, the dose of $8.0 \mathrm{Mg} \mathrm{ha}^{-1}$ of PSC increased it by $28.66 \%$ (225 grains per plant), when compared to the control. On the other hand, when the control was compared to mineral fertilization, it showed a $46.94 \%$ decrease (-360 grains per plant), and the other treatments showed no significant differences. In 2014, the highest number of grains per plant was observed for the $12.0 \mathrm{Mg} \mathrm{ha}^{-1}$ dose, with an increase of 225 grains per plant, in relation to the control. This also applies to the $8.0 \mathrm{Mg} \mathrm{ha}^{-1}$ dose. In 2014 , the number of grains per plant increased $82 \%$ for the mineral fertilizer treatment, if compared to the control without fertilization. The number of grains per plant increased with higher doses of PSC in both years (Table 3). Similar results were found by other authors who applied $\mathrm{N}$ sources to crops such as wheat (Meade et al. 2011), maize (Fischer et al. 1993) and sorghum (Ellen \& Spiertz 1980). It can be explained by the high $\mathrm{N}$ content of PSC, what contributes to the increase in the number of grains per plant, as observed in other studies with millet (Jornada et al. 2005) and rice (Guimarães \& Stone 2003).

Regarding stem diameter, only the dose of $12 \mathrm{Mg} \mathrm{ha}^{-1}$, in 2013, resulted in a significant increase of $21.36 \%(1.14 \mathrm{~mm})$, in comparison with NPK (mineral fertilizer), and $19.60 \%(1.04 \mathrm{~mm})$, when compared to the control. Studying nitrogen levels in winter maize in succession with soybean, Soratto et al. (2007) observed an increase in stem diameter, when applying greater nitrogen doses. Evaluating deep-litter pig manure in soybean, Mennaled et al. (2005) also observed an increase in stem diameter 
with the application of PSC, when compared to the control.

Generally, increasing the applied doses leads to a linear, positive response in dry matter yield (Figure 2). However, for the proso millet yield under normal rainfall, the dose of $8.0 \mathrm{Mg} \mathrm{ha}^{-1}$ seems to be sufficient, what may not apply to drought conditions.

Despite the lack of significant influence on some agronomical characteristics evaluated, applying PSC proved to be an efficient source of $\mathrm{N}$ for proso millet crop, mainly for dry matter and grain yield. PSC represents a promising alternative for the millet crop fertilization and is especially interesting for regions with small properties and high concentration of swine producers, considering the high volume of waste generated (Paillat et al. 2005).

\section{CONCLUSIONS}

1. Pig slurry compost doses close to $8 \mathrm{Mg} \mathrm{ha}^{-1}$ may properly meet the nutritional requirements of the proso millet crop.

2. Proso millet cultivation fertilized exclusively with pig slurry compost can promote dry mass supply to the productive system of up to $7 \mathrm{Mg} \mathrm{ha}^{-1}$ and grain yield up to $4,360 \mathrm{~kg} \mathrm{ha}^{-1}$.

\section{REFERENCES}

ABRANTES, F. L. et al. Nitrogênio em cobertura e qualidade fisiológica e sanitária de sementes de painço (Panicum miliaceum L.). Revista Brasileira de Sementes, Londrina, v. 32, n. 3, p. 106-115, 2010.

BARRENA, R. et al. Respirometric screening of several types of manure and mixtures intended for composting. Bioresource Technology, Amsterdam, v. 102, n. 2, p. 13671377, 2011.

BASSO, C. J. et al. Rates and application times of nitrogen in proso millet crop. Bioscience Journal, Uberlândia, v. 31, n. 4, p. 1030-1036, 2015.

BRASIL. Instituo Nacional de Meteorologia. Normais climatológicas 1961 a 1990. 2016. Available at: $<$ http://www.inmet.gov.br/portal/index.php?r=clima/ normaisclimatologicas>. Acess in: Jan. 2016.

BUSTAMANTE, M. A. et al. Recycling of anaerobic digestates by composting: effect of the bulking agent used. Journal of Cleaner Production, London, v. 47, n. 1, p. 61-69, 2013.
COMISSÃO DE QUÍMICA E FERTILIDADE DE SOLO (CQFS-RS/SC). Manual de adubação e calagem para os Estados do Rio Grande do Sul e Santa Catarina. 10. ed. Porto Alegre: Sociedade Brasileira de Ciência do Solo, 2004.

CONTI, L. D. et al. Soil solution concentrations and chemical species of copper and zinc in a soil with a history of pig slurry application and plant cultivation. Agriculture, Ecosystems \& Environment, Amsterdam, v. 216 , n. 15 , p. 374-386, 2016.

CRUZ, C. D. Programa Genes: biometria. Viçosa: UFV, 2006.

DORAN, J. W.; PARKIN, T. B. Defining and assessing soil quality. In: DORAN, J. W. et al. (Eds.). Defining soil quality for a sustainable environment. Madison: SSSA, 1994.

ELLEN, J.; SPIERTZ, J. H. J. Effect of rate and timing of nitrogen dressings on grain yield formation of winter wheat. Fertilizer Research, Amsterdam, v. 1, n. 3, p. 77190, 1980.

EMPRESA BRASILEIRA DE PESQUISA AGROPECUÁRIA (Embrapa). Centro Nacional de Pesquisa de Solos. Sistema brasileiro de classificação de solos. 3. ed. Rio de Janeiro: Embrapa, 2013.

FISCHER, R. A.; HOWE, G. N.; IBRAHIM, Z. Irrigated spring wheat and timing and amount of nitrogen fertilizer. Field Crops Research, Amsterdam, v. 33, n. 58, p. 37-56, 1993.

FUKUMOTO, Y. et al. Effects of struvite formation and nitratation promotion on nitrogenous emissions such as $\mathrm{NH}_{3}, \mathrm{~N}_{2} \mathrm{O}$ and $\mathrm{NO}_{3}$ during swine manure composting. Bioresource Technology, Amsterdam, v. 102, n. 2, p. 1468 1474, 2011.

GIACOMINI, D. A. et al. Mitigação das emissões de amônia por zeólitas naturais durante a compostagem de dejetos de suínos. Pesquisa Agropecuária Brasileira, Brasília, DF, v. 49, n. 7, p. 521-530, 2014.

GIACOMINI, S. J. et al.Transformações do nitrogênio no solo após adição de dejeto líquido e cama sobreposta de suínos. Pesquisa Agropecuária Brasileira, Brasília, DF, v. 48, n. 2, p. 211-219, 2013.

GIACOMINI, S. J.; AITA, C. Cama sobreposta e dejetos líquidos de suínos como fonte de nitrogênio ao milho. Revista Brasileira de Ciência do Solo, Viçosa, v. 32, n. 1, p. 195-205, 2008.

GUIMARÃES, C. M.; STONE, L. F. Adubação nitrogenada do arroz de terras altas no sistema de plantio direto. Revista Brasileira de Engenharia Agrícola e Ambiental, Campina Grande, v. 7, n. 2, p. 210-214, 2003. 
HEPPERLY, P. et al. Compost, manure and synthetic fertilizer influences crop yields, soil properties, nitrate leaching and crop nutrient content. Compost Science \& Utilization, Philadelphia, v. 17, n. 3, p. 117-126, 2009.

HUANG, G. F. et al. Transformation of organic matter during co-composting of pig manure with sawdust. Bioresource Technology, Amsterdam, v. 97, n. 15, p. 18341842, 2006.

JORNADA, J. B. J. et al. Efeito da irrigação, épocas de corte da forragem e doses de nitrogênio sobre o rendimento de sementes de milheto. Revista Brasileira de Sementes, Londrina, v. 27, n. 2, p. 50-58, 2005.

LINDNER, E. A. Aspectos práticos do manejo de dejetos suínos. Florianópolis: Epagri/Embrapa-CNPSA, 1995.

LOECKE, T. D. et al. Corn growth responses to composted and fresh solid swine manure. Crop Science, Madison, v. 44, n. 1, p. 177-184, 2004.

LU, H. et al. Earliest domestication of common millet (Panicum miliaceum) in east Asia extended to 10,000 years ago. Proceedings of the National Academy of Sciences of the United States of America, Washington, DC, v. 106, n. 25, p. 7367-7372, 2009.

LYIMO, H. J. F. et al. Composted cattle and poultry manures provide excellent fertility and improved management of gray leaf spot in maize. Field Crops Research, Amsterdam, v. 126, n. 15, p. 97-103, 2012.

MACDONALD, G. K. et al. Agronomic phosphorus imbalances across the world's croplands. Proceedings of the National Academy of Sciences of the United States of America, Washington, DC, v. 108, n. 25, p. 3086-3091, 2011.

MAKARA, A.; KOWALSKI, Z. Pig manure treatment and purification by filtration. Environmental Engineering and Management Journal, Iasi, v. 161, n. 3, p. 317-324, 2015.

MEADE, G. et al. Ammonia and nitrous oxide emissions following land application of high and low nitrogen pig manures to winter wheat at three growth stages. Agriculture, Ecosystems \& Environment, Amsterdam, v. 140, n. 1-2, p. 208-217, 2011.

MEDEIROS, L. T. et al. Produção e qualidade da forragem de capim-marandu fertirrigada com dejetos líquidos de suínos. Revista Brasileira de Zootecnia, Viçosa, v. 36, n. 2, p. 309-318, 2007.

MENALLED, F. D.; BUHLER, D. D.; LIEBMAN, M. Composted swine manure effects on germination and early growth of crop and weed species under greenhouse conditions. Weed Technology, New York, v. 19, n. 4, p. 784-789, 2005.
MENNALED, F. D.; LIEBMAN, M.; BUHLER, D. D. Impact of composted swine manure and tillage on common waterhemp (Amaranthus rudis) competition with soybean. Weed Science, Amsterdam, v. 2, n. 52, p. 605-613, 2004.

MOREnO, J. A. Clima do Rio Grande do Sul. Porto Alegre: Secretaria da Agricultura, 1961.

MORENO, L. S. B. et al. Base temperature determination of tropical Panicum spp. grasses and its effects on degreeday-based models. Agricultural and Forest Meteorology, Amsterdam, v. 186, n. 1, p. 26-33, 2014.

MUHAMMAD, I. et al. Response of wheat growth and yield to various levels of compost and organic manure. Pakistan Journal of Botany, Faisalabad, v. 40, n. 5, p. 2135-2141, 2008.

MUNESHWAR, S. et al. Effect of integrated use of fertilizer nitrogen and farmyard manure or green manure on transformation of N, K and S and productivity of ricewheat system on a Vertisol. Journal of the Indian Society of Soil Science, New Deli, v. 49, n. 2, p. 430-435, 2001.

NEVENS, F.; REHEUL, D. The application of vegetable, fruit and garden waste (VFG) compost in addition to cattle slurry in a silage maize monoculture: nitrogen availability and use. European Journal of Agronomy, Paris, v. 19, n. 2, p. 189-203, 2003.

PAILLAT, J. M. et al. Effet du compostage dèfluents porcins sur les émissions gazeuses et les teneurs en éléments polluants. Rennes: INRA, 2005.

PRAPASPONGSA, T. et al. LCA of comprehensive pig manure management incorporating integrated technology systems. Journal of Cleaner Production, New York, v. 18, n. 14, p. 1413-1422, 2010.

ROSE, D. J.; SANTRA, D. K. Proso millet (Panicum miliaceum $L$.) fermentation for fuel ethanol production. Industrial Crops and Products, Amsterdam, v. 43, n. 1, p. 602-605, 2013.

SIELING, K.; NI, K.; KAGE, H. Application of pig slurry: first year and residual effects on yield and $\mathrm{N}$ balance. European Journal of Agronomy, Amsterdam, v. 59, n. 1, p. 13-21, 2014.

SORATTO, R. P. et al. Doses e épocas de aplicação de nitrogênio em cobertura na cultura do painço (Panicum miliaceum L.). Ciência e Agrotecnologia, Lavras, v. 3, n. 6, p. 1661-1667, 2007.

STEINFELD, H. et al. Livestock long shadow. Rome: FAO, 2006.

SZOGI, A. A. et al. Phosphorus recovery from pig manure solids prior to land application. Journal of Environmental Management, London, v. 157, n. 1, p. 1-7, 2015. 
TEDESCO, M. J. et al. Anaílises de solo, planta e outros materiais. 2. ed. Porto Alegre: UFRGS, 1995.

THU, C. T. T. et al. Manure management practices on biogas and non-biogas pig farms in developing countries using livestock farms in Vietnam as an example. Journal of Cleaner Production, New York, v. 27, n. 3, p. 64-71, 2012.

TILLING, A. K. et al. Remote sensing of nitrogen and water stress in wheat. Field Crops Research, Amsterdam, v. 104, n. 3, p. 77-85, 2007.

VAN RUITEN, A. Phosphate recovery from animal manure: the possibilities in the Netherlands. Amsterdam: CEEP, 1998.
VITOUSEK, P. M. et al. Agriculture nutrient imbalances in agricultural development. Science, Washington, DC, v. 324, n. 4, p. 15199-1520, 2009.

WANG, Y. S. et al. Alternate partial root-zone irrigation improves fertilizer-N use efficiency in tomatoes. Irrigation science, New York, v. 31, n. 5, p. 589-598, 2013.

ZARNKOW, M. et al. Impact of proso millet (Panicum miliaceum $\mathrm{L}$.) varieties on malting quality. Journal of the American Chemical Society, Washington, DC, v. 68, n. 1, p. 152-159, 2010. 